\title{
Status of two Coreius species in the Three Gorges Reservoir, China*
}

\author{
XIA Yuguo (夏雨果) $)^{1,2}$, J. LLORET ${ }^{3}$, LI Zhongjie (李钟杰) $)^{1}$, ZHANG Tanglin (张堂林) ${ }^{1}$, \\ YE Shaowen (叶少文) ${ }^{1}$, LI Wei (李为) $)^{1}$, YUAN Jing (苑晶) ${ }^{1}$, H. A. C. C. PERERA ${ }^{1,2}$, \\ LIU Jiashou (刘家寿) $)^{1, * *}$ \\ ${ }^{1}$ State Key Laboratory of Freshwater Ecology and Biotechnology, Institute of Hydrobiology, Chinese Academy of Sciences, \\ Wuhan 430072, China \\ ${ }^{2}$ University of Chinese Academy of Sciences, Beijing 100049, China \\ ${ }^{3}$ Faculty of Sciences, Campus Montilivi, University of Girona, 17071 Girona (Catalonia), Spain
}

Received Aug. 31, 2014; accepted in principle Oct. 21, 2014; accepted for publication Feb. 14, 2015

(C) Chinese Society for Oceanology and Limnology, Science Press, and Springer-Verlag Berlin Heidelberg 2015

\begin{abstract}
Dam construction alters natural flow regimes which, in turn, cause significant changes in fish communities during and after impoundment. The construction of the Three Gorges Reservoir, from impoundment of the Changjiang (Yangtze) River, China, may have affected native fish species. Thus, the status of two lotic freshwater fish species, Coreius heterodon and C. guichenoti, were monitored in the Three Gorges Reservoir, including fish abundance, individual composition, growth, condition, and mortality. Data on both species were gathered from upstream, midstream and downstream areas of the reservoir and, where available, from studies published before and after dam construction. Lower abundance, slower growth, a less diversified age structure, poorer fish condition (indicated by hepatosomatic index) and higher mortalities were recorded in sites nearest the dam compared with upstream areas. Furthermore, after final impoundment, individual Coreius species inhabiting the area changed, with young individuals becoming more abundant, while upstream of the reservoir the two Coreius species became smaller at a given age. The results show that the status of the two Coreius species was subject to dramatic changes after impoundment.
\end{abstract}

Keyword: Three Gorges Reservoir; Coreius species; status; age profile; growth; impoundment

\section{INTRODUCTION}

In recent decades, a growing number of hydropower-generating facilities have been built around the world, with a consequent increase in dam construction, especially in Central and South America, Asia and Oceania (Gleick, 1993). In China, the number of dams has increased from 22 in 1950 to 88605 in 2010 (Jia et al., 2010; MWR, 2011). Dams provide economic benefits that include hydropower (WCD, 2000), water supply regulation (Mugabe et al., 2003), flood control (Galat et al., 1998) and navigation (Thorp et al., 1994) among others; however, they now affect over half of all large, freshwater aquatic systems worldwide (Nilsson et al., 2005). River damming is broadly accepted as being responsible for the most significant and widespread impacts on freshwater environments (Dynesius and
Nilsson, 1994).

Hydroelectric development has caused significant changes in fish fauna, including divergence of fish communities (Gehrke et al., 2002), reduced fish abundance (Cushman, 1985), decreased fish biodiversity (Paragamian, 2002), elimination of native species (Holmquist et al., 1998; Liermann et al., 2012) and loss of spawning habitats for migratory fish (Cambray et al., 1997). Simpler levels of species interactions and lower fish abundance have been observed in the upstream areas of dams (Katano et al., 2006). The impact of dams on fish population

\footnotetext{
* Supported by the National Key Technology Research and Development Program of China (No. 2012BAD25B08), the China Three Gorges Corporation Project (No. CT-12-08-01), and the State Key Laboratory of Freshwater Ecology and Biotechnology (No. 2014FBZ04)

** Corresponding author: jsliu@ihb.ac.cn
} 
characteristics has been widely studied (Perera et al., 2013). However, previous investigations have mainly focused on the effects on population numbers (Rypel and Bayne, 2009). Decreases in riverine fish populations or even the extinction of riverine fish species have been reported in many rivers after impoundment (WCD, 2000; Jackson and Marmulla, 2001; Park et al., 2003; Xenopoulos and Lodge, 2006). Moreover, the ecological effects of the loss of migratory native fish species due to the damming of riverine ecosystems were more widespread than the bottom-up effects (Greathouse et al., 2006). In particular, a large part of the decline in productivity and reduction of fish growth has been attributed to the construction of dams (Paragamian, 2002).

The Three Gorges Dam (TGD), currently the largest hydroelectric dam in the world in terms of installed capacity, was completed recently (2012) in the upper Changjiang (Yangtze) River in China (Wu et al., 2003). It is also the largest reservoir in the world in terms of water capacity (about $40 \mathrm{~km}^{3}$ ), total surface area $\left(1080 \mathrm{~km}^{2}\right)$ and total length (approximately $667 \mathrm{~km}$ ) when the water level is at its maximum of $175 \mathrm{~m}$ above sea level (a.s.l.) (Fu et al., 2010). This provides an ideal location for investigating the effects of large dams on native fish populations.

Coreius heterodon (Bleeker, 1865) and C. guichenoti (Sauvage et Dabry, 1874) are two indigenous demersal and potamodromous (semimigratory) cyprinid fish with similar food habits (He, 1980; Liu et al., 2012). In the Changjiang River, $C$. heterodon is primarily distributed in the mainstream and large tributaries of the middle reaches (Liu et al., 1990; Yan, 2005), while C. guichenoti is mainly distributed in the upper reaches (Liu et al., 1990; Ding, 1994). The spawning area of $C$. heterodon was mainly located in the Three Gorges Reservoir (TGR) area before impoundment (Anonymous, 1976; Xu et al., 1981; Liu et al., 1990), while that of C. guichenoti was located in the Jinsha and Yalong Rivers (Anonymous, 1976; Xu et al., 1981; Liu et al., 1990). The minimum age of sexual maturity of the two Coreius species is 3 years, and the spawning time extends from April to July when the water temperature is $18-22^{\circ} \mathrm{C}$ (Anonymous, 1976; Xu et al., 1981; Liu et al., 1990; Zhang, 2009). Eggs hatch while drifting downstream with the water flow (Liu et al., 1990). Larvae also grow while drifting downstream, and young and sub-adults migrate upstream for maturation and reproduction (Liu et al., 1990; Zhang, 2009). These two species have long been among the most valuable commercial fish in the Changjiang River (Liu and Cao, 1992; Wu et al., 2007). However, catches, especially of large individuals, have been declining since 1999 (SEPA, 2000-2006). According to 'self-organizing map' model predictions, $C$. guichenoti has a high probability of becoming extinct (Park et al., 2003). An understanding of the population characteristics of riverine fishes and an investigation of their life-history traits are essential for the implementation of appropriate conservation and management measures. The two Coreius species have been the subject of numerous studies in relation to, for example, growth characteristics (Zhou, 2010; Yang et al., 2011a), population dynamics (Yang, 2009), feeding habits (Liu et al., 2012), reproductive ecology (Liu et al., 1990; Cheng, 2008), genetic characteristics (Yuan et al., 2008; Xu and Milliman, 2009; Zhang and Tan, 2010) and prey dynamics (Yu et al., 1984; Tang et al., 2012). However, most studies were conducted before maximum impoundment (2010), and little is known about the potential impact of large-scaled impoundment on the status of these two species. Many fish are apparently resilient to river impoundment and may even thrive in these habitats (Chang et al., 1999; Han et al., 2008).

Although many studies have reported on the ecological impact of the TGD (Wu et al., 2004; Gao, 2007; Yang et al., 2012), most are limited to the riverine reaches downstream of the reservoir (Xie et al., 2007). Some studies have considered the impact on areas upstream from the dam, where damage can also be severe (Park et al., 2003; He et al., 2010; Perera et al., 2013). Nevertheless, most studies on the effects of the TGD have focused on changes in fish species composition and catch statistics (Gao, 2007). Our previous studies on the characteristics of the yellow catfish (Peltobagrus fluvidraco) population (Perera et al., 2013) indicated significant differences at three sites along the longitudinal profile of the TGR and suggested there was a need for further studies to evaluate the status of other native fish species after this major impoundment. The purpose of the current study was to evaluate large-scale spatial variations in the status and individual changes of two Coreius species over the longitudinal profile of the recently impounded TGR on the Changjiang River. The research provides an important case study on the ecological effects of large dams on migratory fish and the status of these two species after maximum impoundment. Our findings could be used to develop conservation strategies and improve management of 


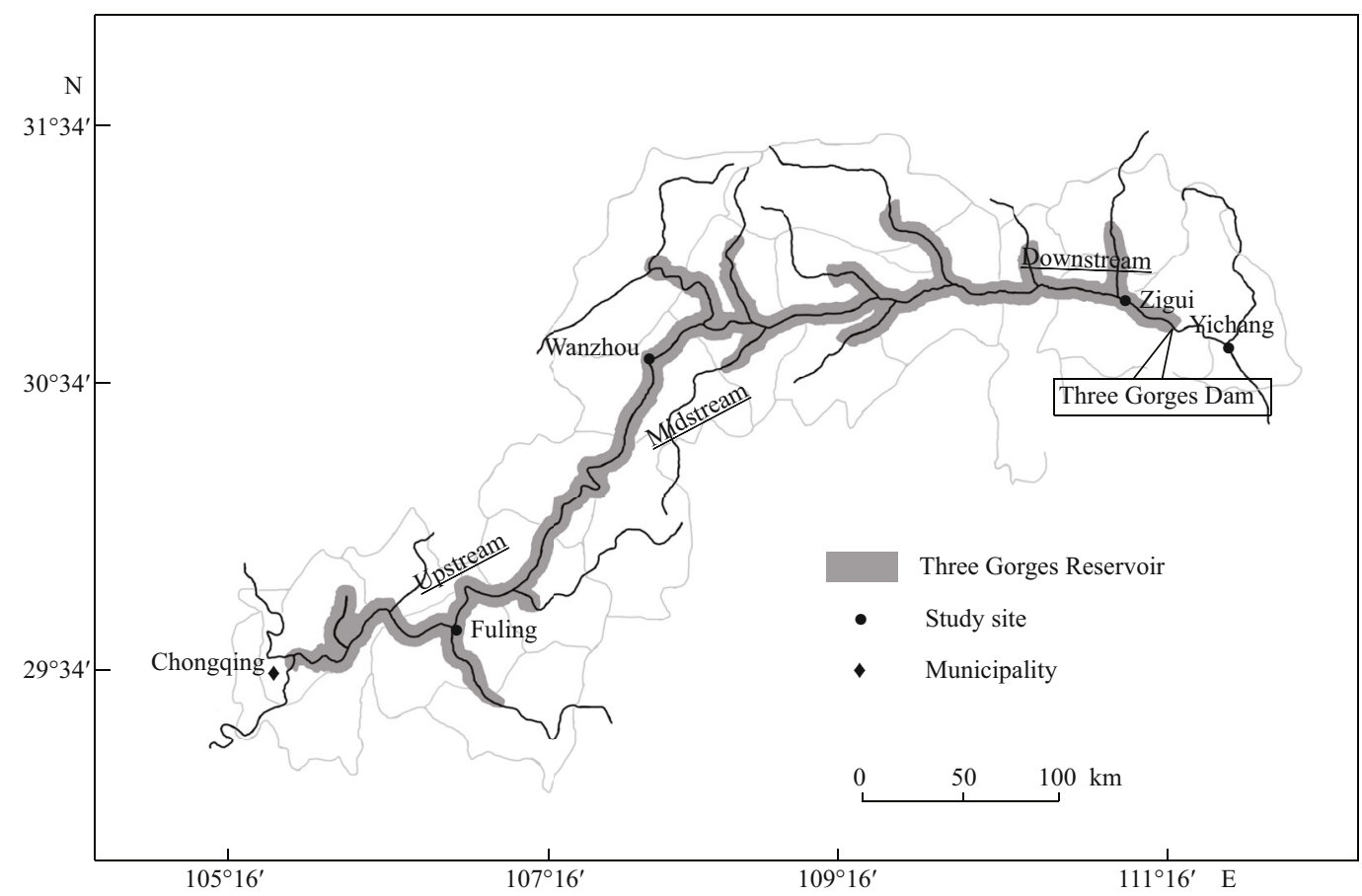

Fig.1 Sampling sites for Coreius. heterodon and C. guichenoti in the Three Gorges Reservoir, China Fuling: upstream; Wanzhou: midstream; Zigui: downstream.

the two Coreius species, and also provide useful guidelines in this regard for other indigenous species.

\section{MATERIAL AND METHOD}

\subsection{Study area}

The first stage in the construction of the TGD was finished in 1997, and the dam was fully completed in 2009. The TGD, located in the upper reaches of the Changjiang River, is $185 \mathrm{~m}$ high. The storage capacity of the TGR was increased, in phases, from $135 \mathrm{~m}$ a.s.l. in 2003 to $156 \mathrm{~m}$ a.s.l. in 2006, and to $175 \mathrm{~m}$ a.s.l. in 2010, resulting in a final, maximum capacity of 39.3 billion $\mathrm{m}^{3}$. Three sampling sites were chosen to collect the two Coreius species along the longitudinal axis of the TGR (Fig.1). Zigui, the downstream area, is located almost immediately adjacent to the dam $\left(30^{\circ} 51^{\prime} 17.6^{\prime \prime} \mathrm{N}, 111^{\circ} 00^{\prime} 04.4^{\prime \prime} \mathrm{E}\right)$; Wanzhou, the midstream area, is located about $300 \mathrm{~km}$ from the dam $\left(30^{\circ} 49^{\prime} 13.7^{\prime \prime} \mathrm{N}, 108^{\circ} 23^{\prime} 46.6^{\prime \prime} \mathrm{E}\right)$ and Fuling, the upstream area, is located $\sim 500 \mathrm{~km}$ from the dam $\left(29^{\circ} 42^{\prime} 48.5^{\prime \prime} \mathrm{N}, 107^{\circ} 23^{\prime} 57.7^{\prime \prime} \mathrm{E}\right)$. When the reservoir water level is at $135 \mathrm{~m}$ a.s.1., the depths (Lü et al., 2007), flow velocities (Zeng, 2006; Lü et al., 2007) and reservoir widths (unpublished data) at the downstream, midstream and upstream area were, respectively, approximately 100,42 and $31 \mathrm{~m}$, approximately $0.023,0.280$ and $0.705 \mathrm{~m} / \mathrm{s}$, and approximately $1.5,0.9$ and $0.7 \mathrm{~km}$. The upstream area has a sandy bottom, while the midstream and downstream area have muddy bottoms (Liu, 2009). Very few benthic organisms, or none, have been recorded from the three sampling sites (Liu, 2009). The plant community in the water-level-fluctuating zone in the upstream area was dominated by herbaceous plants, but closer to the dam there is less species diversity of herbaceous plants (Xia, 2011).

\subsection{Fish sampling and data collection}

Coreius heterodon and C. guichenoti were sampled monthly using three-layer gillnets and long-lines between November 2010 and October 2011 at the three sites. Landings from five fishing boats were recorded at each location every month. The gill nets were $100-120 \mathrm{~m}$ in length and $10-20 \mathrm{~m}$ in height (three-layer multi-mesh gillnets with a central mesh size of 4-8 cm and outer mesh sizes of 10-20 cm). The long-lines were $2 \mathrm{~km}$ in length, with a baited hook every $4 \mathrm{~m}$. Mealworms (Tenebrio molitor) or chironomid larva were used as baits. The gillnets and long-lines were deployed at twilight, and hauled and sampled for fish after $12 \mathrm{~h}$. The total length (TL), standard length (SL) and body weight $(W)$ of each captured specimen were measured to the nearest 1 $\mathrm{mm}$ and $0.01 \mathrm{~g}$, respectively. The scales, gonads and livers were subsequently removed in the field. 
The gonads and livers were weighed to the nearest $0.001 \mathrm{~g}\left(W_{\mathrm{G}}\right.$ and $\left.W_{\mathrm{L}}\right)$. Five to ten scales from the belly below the dorsal fin and lateral line were collected to determine their age. For age determination, the annual rings were counted and annuli diameter were recorded following the procedure of Yan (2005). The sex of each specimen was determined by visual inspection of the gonads. Following macroscopic evaluation of the ovaries, the Coreius specimens were classified into six groups according to the stage of development (Zheng and Xiong, 1993): Stage I (immature); Stage II (developing), Stage III (vitellogenesis), Stage IV (mature/spawning capability), Stage V (spawning/ actively spawning) and Stage VI (spent/regressing).

\subsection{Data analysis}

Hepatosomatic index (HSI), which serves as an indicator of the nutritional status of individual fish (Lloret et al., 2014), was expressed as liver weight (g) as a percentage of eviscerated body weight $(\mathrm{g})$. HSI $=100 \times$ (liver weight / body weight $)$.

Length-frequency data with constant class size were modeled using the von Bertalanffy growth function (VBGF) using ELEFAN I (Electronic Length Frequency Analysis) as described in Zhuang and Cao (1999). ELEFAN I is a routine used to identify the best fit for the growth curve to a length-frequency dataset arranged sequentially (Pauly and David, 1981).

Le Cren's relative condition factor $\left(K_{n}\right)$ —used as an indicator of body condition-was calculated as $K_{n}=W / W_{\mathrm{e}}$, where $W$ is the observed weight of the fish and $W_{\mathrm{e}}$ is the estimated weight, derived from $W-L$ relationship representing all individuals in all samples (Lloret et al., 2014).

The instantaneous rate of total mortality $(Z)$ for each year class sampled at each site was determined using two methods: (1) Hoenig Model: $Z_{1}=1 /\left[c_{1}\left(t_{\max }-\right.\right.$ $\left.\left.t_{\mathrm{c}}\right)\right]$, s.e. $(Z)=\operatorname{SQR}\left(c_{2} Z^{2}\right)^{1 / 2}$, where $c_{1}$ and $c_{2}$ are functions of $N$ (Hoenig and Lawing, 1982), $t_{\max }$ is the maximum age in years observed in a given stock and as an option, $t_{\mathrm{c}}$ is the mean age at first capture and $N$ is the sample size from which $t_{\max }$ is estimated (Hoenig, 1983); (2) $Z_{2}=k\left(L_{\infty}-L_{\text {mean }}\right) /\left(L_{\text {mean }}-L^{\prime}\right)$, where $L_{\infty}$ is the asymptotic length measured from total length; $k$ is the curvature parameter of the VBGF; $L_{\text {mean }}$ is the mean length of the fish in a sample representing a steadystate population and $L^{\prime}$ is the cut-off length (Beverton and Holt, 1956). These estimates were averaged as the instantaneous total mortality rates $\left(Z=\left(Z_{1}+Z_{2}\right) / 2\right)$ (Yang et al., 2009; Maunder and Wong, 2011). The instantaneous rate of natural mortality $(M)$ was determined using Pauly's $M$ Equation (Pauly, 1980): $\log (M)=-0.0066-0.2790 \log \left(L_{\infty}\right)+0.6543 \log (k)+0.4634(T)$, where $L_{\infty}$ is the asymptotic length measured from total length; $k$ is the VBGF curvature parameter and $T$ is the mean annual water temperature $\left(18^{\circ} \mathrm{C}\right)$ of the habitat (Yang, 2009). The instantaneous rate of fishing mortality $(F)$ was estimated from the relationship: $F=Z-M$, where $Z$ and $M$ are as defined above.

Mortality estimates and VBGF parameters were calculated using FiSAT II 1.2.2. Growth rates from the three sites were estimated from length-frequency data with constant class size separately for males and females. Power regressions of length-weight relationships were calculated for both species between sites and the exponent $b$-values have been estimated using the equation $W=a \mathrm{TL}^{b}$. Analysis of covariance (ANCOVA) was used to test difference in $b$-values between sexes and between sites. Differences in HSI between sites were evaluated using analysis of variance (ANOVA) with Tukey's post-hoc comparison test. The Mann-Whitney test was used to test differences in the Le Cren's condition index $\left(K_{n}\right)$ and the total length of both species between sites. Crosstabulation $\left(\chi^{2}\right.$ test) was used to test differences in the frequency of occurrence between sites. Differences were considered to be significant at $P<0.05$. Statistical analysis was performed using SPSS 16.0 (SPSS Inc., Chicago, IL, USA).

\section{RESULT}

\subsection{Coreius stocks at different sites along the TGR}

A total of 396 and 817 individuals of $C$. heterodon and $C$. guichenoti were collected, respectively, from the three sites along the TGR during our investigations. All fish were immature juveniles (Stage I) and/or young adults (Stage II). There were significant differences in the frequency of occurrence for both C. heterodon $\left(\chi^{2}=12.829, P<0.05\right)$ and $C$. guichenoti $\left(\chi^{2}=20.285, P<0.05\right)$ between sites. A $100 \%$ frequency of occurrence was recorded in the upstream area, but only $33.3 \%$ for $C$. heterodon and $8.3 \%$ for C. guichenoti were recorded in the downstream area (Fig.2).

\subsection{Age and growth at different sites along the TGR}

The TL of $C$. heterodon ranged 127-380 $\mathrm{mm}$ with a mean \pm SD of $218.2 \pm 46.2 \mathrm{~mm}$ in the upstream area (Fuling), 170-407 mm with a mean of $302.8 \pm 53.0 \mathrm{~mm}$ 
in the midstream area (Wanzhou) and 110-303 mm with a mean of $172.9 \pm 50.2 \mathrm{~mm}$ in the downstream area (Zigui) (Figs.3 and 4). TL of C. heterodon specimens collected from the downstream area was significantly smaller than those of from the midstream or upstream areas (Mann-Whitney test, $P<0.05$ ). TL of $C$. guichenoti ranged $85-322 \mathrm{~mm}$ with a mean value of $161.9 \pm 45.2 \mathrm{~mm}$ in the upstream area, 104 $318 \mathrm{~mm}$ with a mean of $181.0 \pm 52.4 \mathrm{~mm}$ in the midstream area, but, in the downstream area, only one C. guichenoti specimen with a TL of $180 \mathrm{~mm}$ was recorded. The mean size of $C$. guichenoti specimens collected from the upstream area was significantly smaller than those of from the midstream area (MannWhitney test, $P<0.01$ ) (Fig.5).

The age structure of $C$. heterodon specimens collected from the three sites contained four age groups ranging from 1 to 4 years. However, the

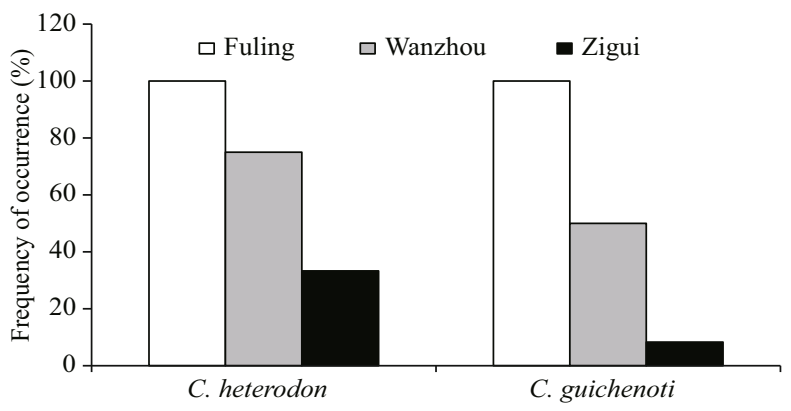

Fig.2 Frequency of occurrence of Coreius heterodon and C. guichenoti at different sites in Three Gorges Reservoir

Fuling: upstream; Wanzhou: midstream; Zigui: downstream. dominant age composition differed between the three sites: 3-year-old specimens dominated the midstream area, 1-2 year olds in the upstream area and 1 year olds in the downstream area (Fig.6a).

The age structure of $C$. guichenoti specimens collected from the upstream and midstream areas contained three age groups ranging from 1 to 3 years, with 1-year-old specimens dominating both areas. In the downstream area, only a single 2-year-old specimen was recorded over the 12-month research

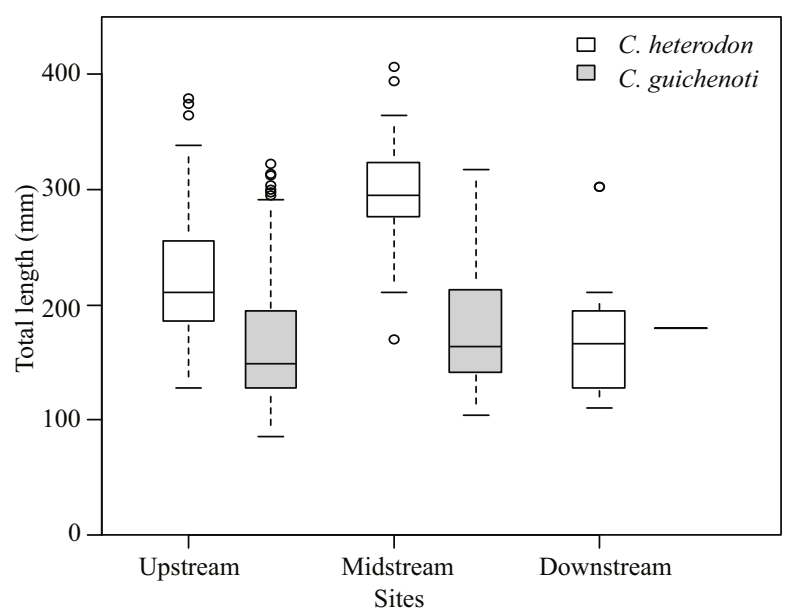

Fig.3 Box plots of total length of Coreius heterodon and C. guichenoti collected at three different sites over a 12-month period from November 2010 to October 2011

Upstream (mean TL \pm SD): $218.2 \pm 46.2 \mathrm{~mm}$; Midstream: $302.8 \pm 53.0$ $\mathrm{mm}$; Downstream: $172.9 \pm 50.2 \mathrm{~mm}$. Squares denote mean values; boxes denote quartiles and whiskers represent minimum and maximum total length. Circles represent outliers. Fuling: upstream; Wanzhou: midstream; Zigui: downstream.

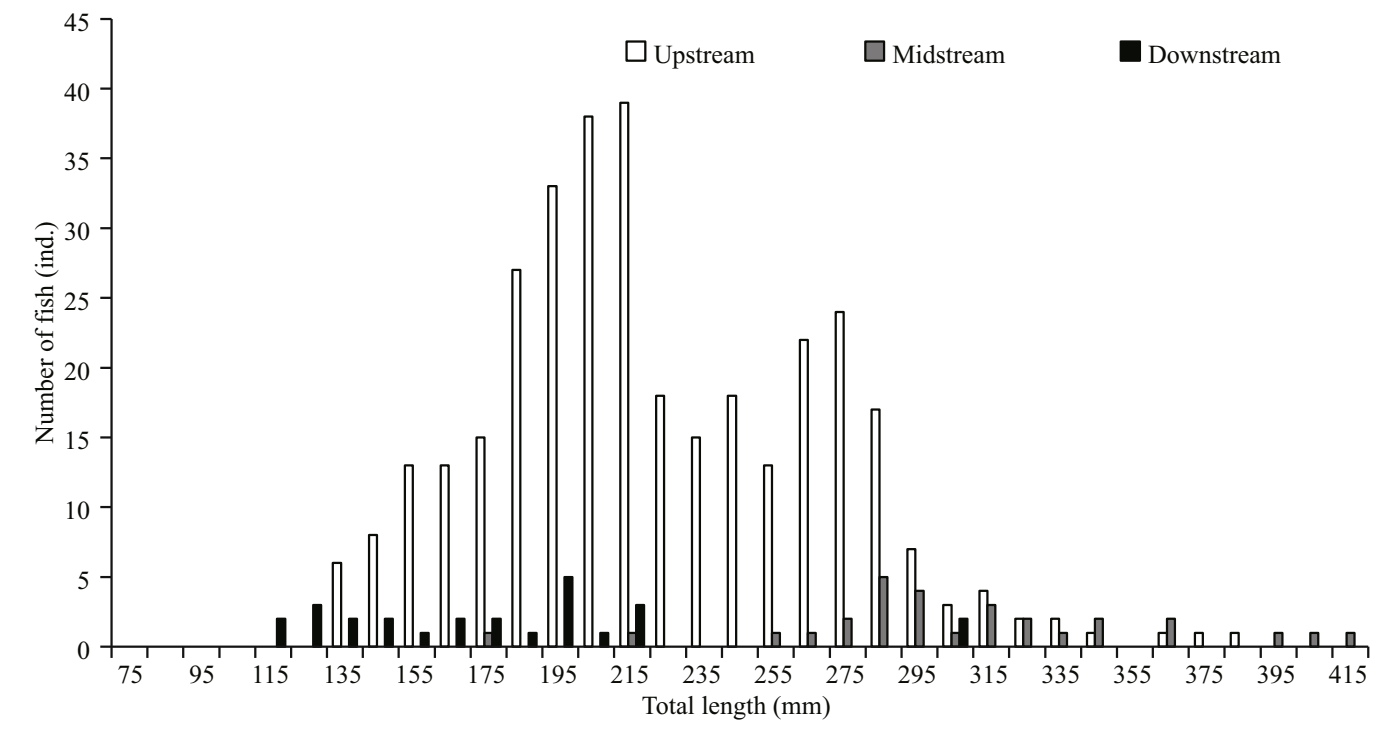

Fig.4 Total length distribution of Coreius heterodon at the three sampling sites in the Three Gorges Reservoir over a 12-month period from November 2010 to October 2011 
CHIN. J. OCEANOL. LIMNOL.,

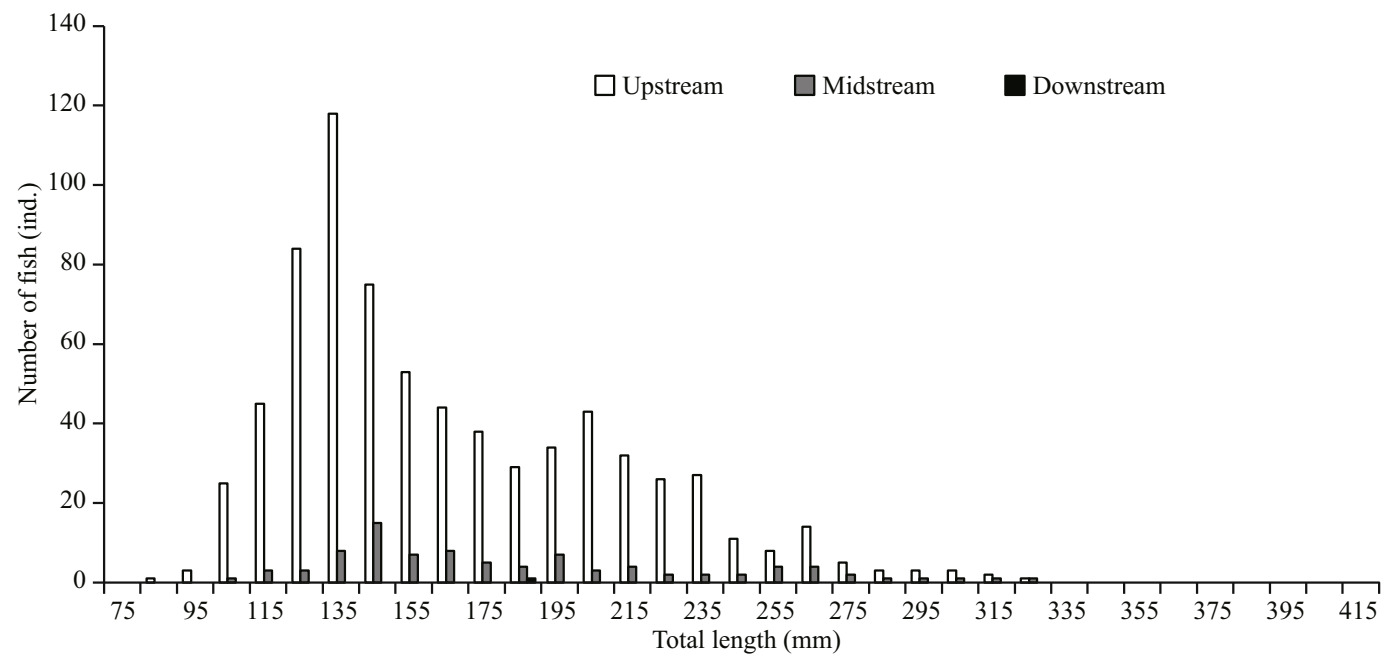

Fig.5 Total length distribution of Coreius guichenoti at three sampling sites in the Three Gorges Reservoir over a 12-month period from November 2010 to October 2011.
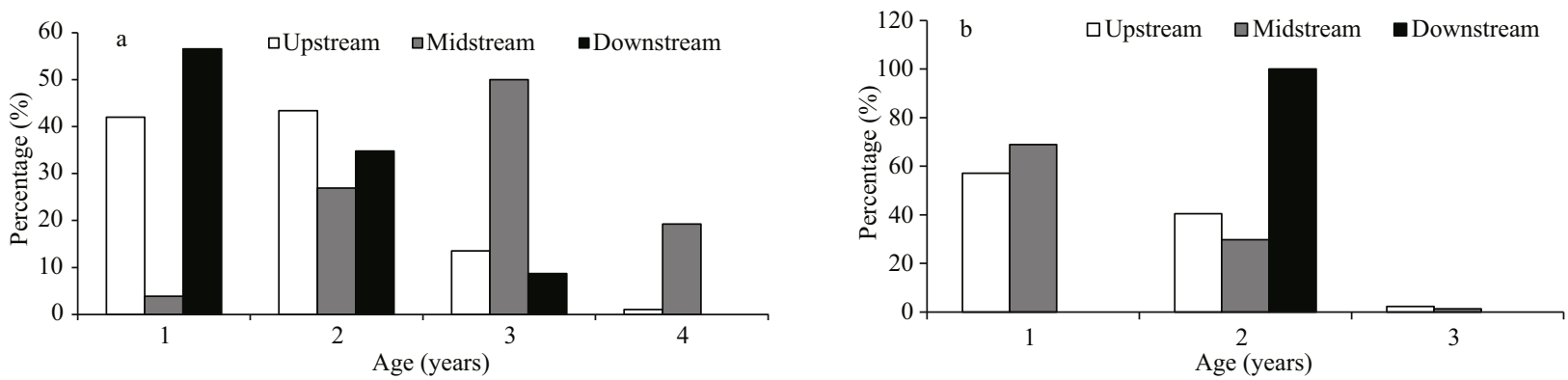

Fig.6 Age distribution of Coreius heterodon (a) and $C$. guichenoti (b) at the three sampling sites in the Three Gorges Reservoir over a 12-month period from November 2010 to October 2011
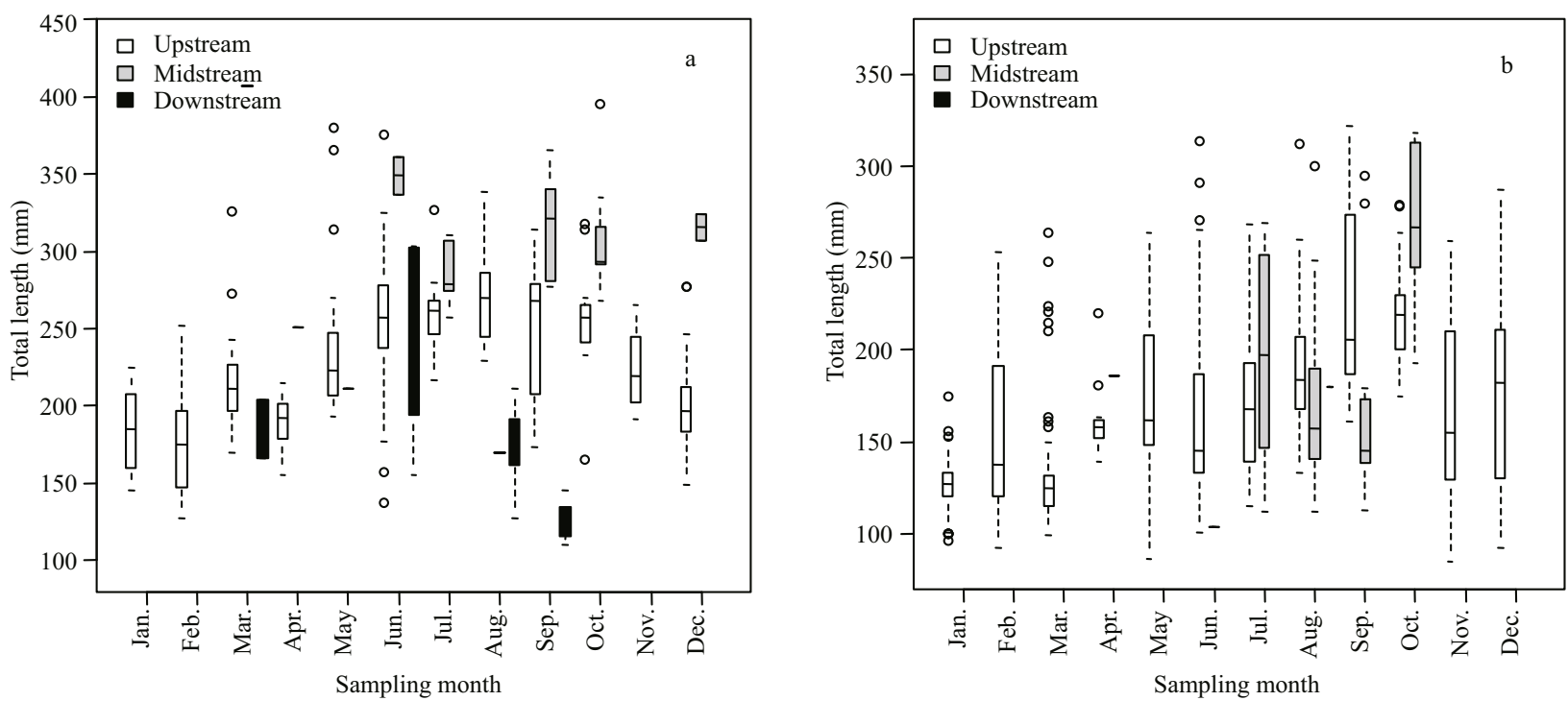

Fig.7 Total length of specimens of (a) Coreius heterodon and (b) C. guichenoti collected over a 12-month period from November 2010 to October 2011 at the three sampling sites in the Three Gorges Reservoir

Squares denote median, boxes denote quartiles and whiskers represent minimum and maximum total length. Circles represent outliers.

period of 2010-2011 (Fig.6b).

Monthly changes in total length (TL, mm) for the three sampling sites of $C$. heterodon and C. guichenoti are shown in Fig.7a and b, respectively. In both species, TL steadily increased from April to July, and decreased from August to December in the upstream 

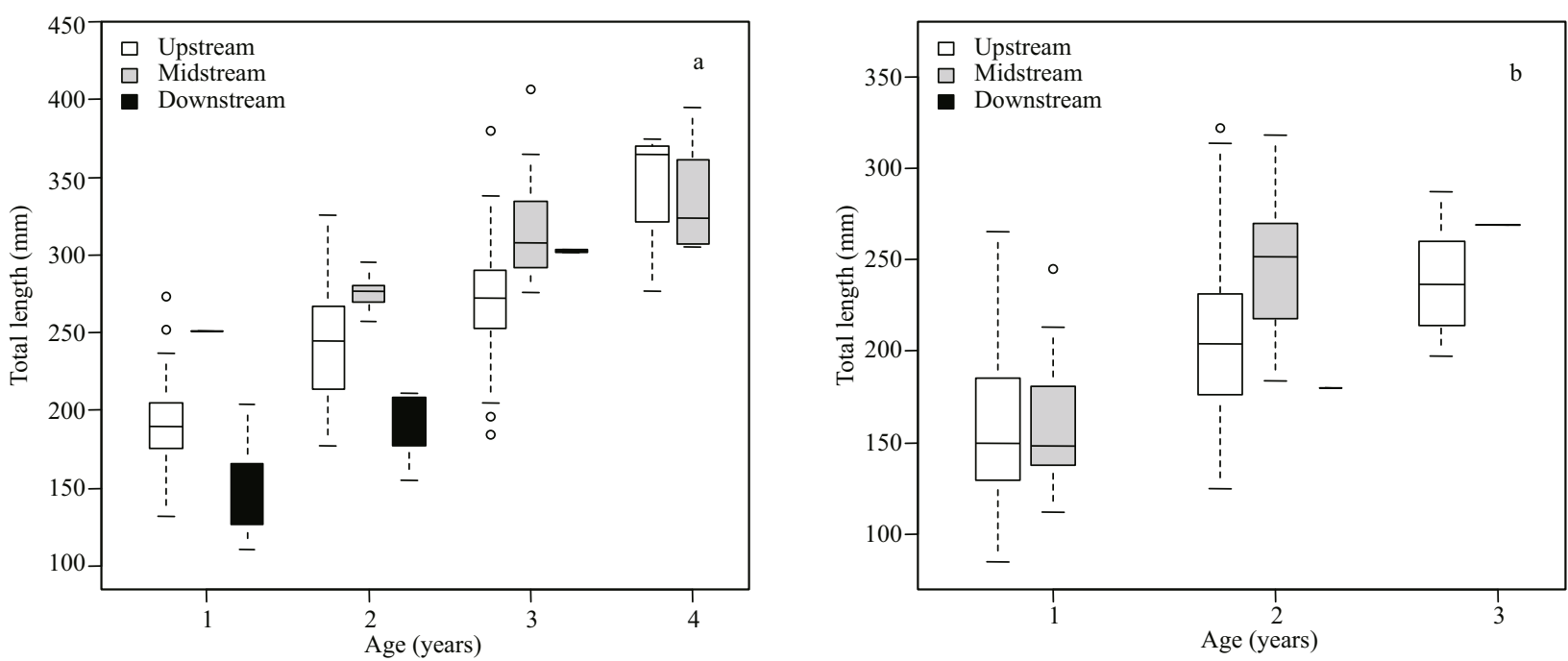

Fig.8 Total length of (a) C. heterodon and (b) C. guichenoti at different ages from the three sampling sites in Three Gorges Reservoir

Squares denote median, boxes denote quartiles and whiskers represent minimum and maximum total length. Circles represent outliers.

Table 1 Summary of the Von Bertalanffy growth parameters, Le Cren's condition index and HSI of Coreius sp. at three sites along the Three Gorges Reservoir

\begin{tabular}{ccccccccc}
\hline \multirow{2}{*}{ Locations } & \multicolumn{9}{c}{ C. heterodon } & \multicolumn{3}{c}{ C. guichenoti } \\
\cline { 2 - 8 } & $L_{\infty}(\mathrm{mm})$ & $k$ & $K_{n}($ mean $\pm \mathrm{SD})$ & HSI $($ mean $\pm \mathrm{SD})$ & $L_{\infty}(\mathrm{mm})$ & $k$ & $K_{n}(\mathrm{mean} \pm \mathrm{SD})$ & HSI $(\mathrm{mean} \pm \mathrm{SD})$ \\
\hline Upstream & 400.0 & 0.24 & $1.00 \pm 0.098^{\mathrm{a}}$ & $2.05 \pm 1.26^{\mathrm{a}}$ & 341.3 & 0.31 & $1.00 \pm 0.117^{\mathrm{a}}$ & $2.97 \pm 1.45^{\mathrm{d}}$ \\
Midstream & 431.5 & 0.09 & $1.00 \pm 0.109^{\mathrm{a}}$ & $1.31 \pm 0.68^{\mathrm{b}}$ & 341.3 & 0.15 & $1.01 \pm 0.099^{\mathrm{a}}$ & $2.23 \pm 0.82^{\mathrm{e}}$ \\
Downstream & 326.6 & 0.08 & $1.01 \pm 0.100^{\mathrm{a}}$ & $0.84 \pm 0.44^{\mathrm{c}}$ & - & - & - \\
\hline
\end{tabular}

Different letters indicates significant differences $(P<0.05)$.

site. The TL of $C$. heterodon at a given age in the downstream area was lower than those from the midstream or upstream areas (Fig.8). The proportion of large and older individuals of $C$. heterodon in the midstream area was greater than in the other sites, while the majority of large and older $C$. guichenoti individuals were collected in the upstream area.

Weight-length $(W-L)$ relationships were first calculated individually for each sex. The individual $W$ of both $C$. heterodon and C. guichenoti displayed no significant difference between the sexes (ANCOVA, $P>0.05$, TL as the covariate). Therefore, the data from females and males were combined, and the $W-L$ relationship for each species was established. For $C$. heterodon, the $W-L$ functions were $W=1.55 \times 10^{-6}$ $\mathrm{TL}^{3.300}, R^{2}=0.980, W=2.40 \times 10^{-6} \mathrm{TL}^{3.222}, R^{2}=0.966$ and $W=2.16 \times 10^{-6} \mathrm{TL}^{3.241}, \quad R^{2}=0.988$ in the upstream, midstream and downstream area, respectively. The $b$ values (i.e. the exponents of TL) were significantly different between each two site (ANCOVA, $P<0.01$ ). For $C$. guichenoti, the $W-L$ functions were $W=1.19 \times$ $10^{-5} \mathrm{TL}^{2.944}, \quad R^{2}=0.981$ and $W=6.65 \times 10^{-6} \mathrm{TL}^{3.065}$,
$R^{2}=0.986$ in the upstream and midstream area, respectively. The $b$ values were significantly different between the two sites (ANCOVA, $P<0.01$ ).

The final VBGF coefficient estimates for each site are summarized in Table 1. Growth rates at the three sites differed. The highest $k$ values for $C$. heterodon and $C$. guichenoti were found in the upstream area, while the lowest were found downstream. $C$. heterodon showed the highest $L_{\infty}$ in the midstream area and the lowest in the downstream site, while $C$. guichenoti displayed the same $L_{\infty}$ in both the upstream and midstream areas.

Although there were no significant differences in $K_{n}$ between the three sites for either species $(P>0.05)$ (Table 1), significant differences in HSI between sites and species were found (Table 1). For the two species, the HSI of individuals collected from the upstream site was significantly higher than those of individuals collected from midstream $(P<0.05)$. For $C$. heterodon, the HSI in the midstream site was significantly higher than in the downstream area $(P<0.05)$. 
CHIN. J. OCEANOL. LIMNOL.,

Table 2 Age and standard length of $C$. heterodon from different periods and at different sampling sites in the Changjiang River

\begin{tabular}{|c|c|c|c|c|c|c|c|c|c|c|c|c|c|}
\hline \multirow{2}{*}{ Sampling sites } & \multirow{2}{*}{ Year } & \multicolumn{11}{|c|}{ Standard length $(\mathrm{mm})$ and percentage $(\%)$ at each age } & \multirow{2}{*}{ Source } \\
\hline & & & 1 & 2 & 3 & 4 & 5 & 6 & 7 & 8 & 9 & $10-13$ & \\
\hline \multirow{2}{*}{$\begin{array}{c}\text { Mainstream and } \\
\text { Hanjiang River }\end{array}$} & \multirow{2}{*}{ 1973-1978 } & $\mathrm{SL}$ & 139 & 192 & 277 & 328 & 371 & 393 & 407 & 444 & 464 & $470-529$ & \multirow{2}{*}{ [1] } \\
\hline & & $\%$ & 10.7 & 18.2 & 7.1 & 31.5 & 10.3 & 8.6 & 5.4 & 4.5 & 1.7 & 2.1 & \\
\hline \multirow{2}{*}{ Yibing to Jiangjin } & \multirow{2}{*}{1973} & $\mathrm{SL}$ & 216 & 251 & 291 & 328 & 405 & & & & & & \multirow{2}{*}[2]{} \\
\hline & & $\%$ & 4 & 17 & 36 & 33 & 10 & & & & & & \\
\hline \multirow{2}{*}{ Wanzhou to Wuling } & \multirow{2}{*}{1982} & $\mathrm{SL}$ & & 208 & 286 & 309 & 329 & 361 & 398 & 430 & & & \multirow{2}{*}[3]{} \\
\hline & & $\%$ & & 2.0 & 55.3 & 26.7 & 12.5 & 2.4 & 0.8 & 0.4 & & & \\
\hline \multirow{2}{*}{ Mudong } & \multirow{2}{*}{1992} & $\mathrm{SL}$ & 181 & 214 & 285 & 310 & 333 & 362 & 400 & & & & \multirow{2}{*}[4]{} \\
\hline & & $\%$ & 3.2 & 22.3 & 41.5 & 19.1 & 9.6 & 3.2 & 1.1 & & & & \\
\hline Mid and upper stream & 1990-1995 & $\mathrm{SL}$ & 79 & 189 & 274 & 355 & 406 & 459 & & & & & {$[5]$} \\
\hline \multirow{2}{*}{ Mainstream } & \multirow{2}{*}{ 2003-2004 } & $\mathrm{SL}$ & 162 & 193 & 263 & 300 & 354 & 383 & & & & & \multirow{2}{*}[6]{} \\
\hline & & $\%$ & 2.2 & 32.2 & 38.7 & 22.6 & 3 & 1.3 & & & & & \\
\hline \multirow{2}{*}{ TGR } & \multirow{2}{*}{ 2010-2011 } & SL & 155 & 185 & 233 & 278 & & & & & & & \multirow{2}{*}{ [7] } \\
\hline & & $\%$ & 56.7 & 31.7 & 8.7 & 2.9 & & & & & & & \\
\hline
\end{tabular}

[1] Xu et al., 1981; [2] He, 1980; [3] Leng et al., 1984; [4] Diao and Zhou, 1994 ; [5] Zhuang and Cao 1999; [6] Yan, 2005; [7] Present study. Note: The years in the table represent sampling periods. SL: standard length.

Table 3 Age and standard length of $C$. guichenoti from different periods and at different sampling sites in the Changjiang River

\begin{tabular}{|c|c|c|c|c|c|c|c|c|c|c|}
\hline \multirow{2}{*}{ Sampling sites } & \multirow{2}{*}{ Year } & \multicolumn{8}{|c|}{ SL $(\mathrm{mm})$ and percentage $(\%)$ at each age } & \multirow{2}{*}{ Source } \\
\hline & & & 1 & 2 & 3 & 4 & 5 & 6 & 7 & \\
\hline \multirow{2}{*}{ Panzhihua to Yidu } & \multirow{2}{*}{ 2005-2007 } & SL & 110 & 201 & 266 & 300 & 336 & 363 & 376 & \multirow{2}{*}[1]{} \\
\hline & & $\%$ & 18.3 & 35.4 & 28.4 & 9.9 & 6.1 & 1.6 & 0.5 & \\
\hline \multirow{2}{*}{$\begin{array}{l}\text { Chongqing } \\
\text { and Yichang }\end{array}$} & \multirow{2}{*}{ 2006-2007 } & SL & 135 & 219 & 290 & 334 & 377 & & & \multirow{2}{*}[2]{} \\
\hline & & $\%$ & 63.4 & 26.1 & 8.4 & 1.7 & 0.3 & & & \\
\hline \multirow{2}{*}{ TGR } & \multirow{2}{*}{ 2010-2011 } & SL & 120 & 156 & 199 & & & & & \multirow{2}{*}{ [3] } \\
\hline & & $\%$ & 67.0 & 32.2 & 0.9 & & & & & \\
\hline
\end{tabular}

[1] Cheng, 2008; [2] Yang, 2009; [3] Present study. Note: the years in the table represent sampling periods. SL: standard length.

\subsection{Mortality rate estimation}

The modeling process is size-related, and the precision of estimates is closely related to the ratio of sample size to the number of length classes in each sample (Gerritsen and McGrath, 2007). Therefore, we combined the length-frequency data of the three sampling sites to provide adequate results on mortality rates. Instantaneous total mortality rates $Z$ of $C$. heterodon, estimated from Hoenig's and Beverton and Holt's methods were 1.951/year $\left(Z_{1}\right)$ and $0.378 /$ year $\left(Z_{2}\right)$, respectively, with an average of $1.165 /$ year. However, for $C$. guichenoti, these values of $Z$ were $2.734 /$ year $\left(Z_{1}\right)$ and $0.696 /$ year $\left(Z_{2}\right)$, respectively, with an average of $1.715 /$ year. Pauly's estimates of $M$ for $C$. heterodon and C. guichenoti were 0.458 and $0.652 /$ year, respectively. Estimates of $F$ obtained from the average mortality for $C$. heterodon and $C$. guichenoti were $0.707 /$ year and $1.063 /$ year, respectively.

\subsection{Historical changes in the Coreius sp. population structure}

After the impoundment, the $C$. heterodon age structure contained four age groups with age-1 group accounting for $56.7 \%$ of the total. However, previous studies recorded between five and seven age groups in the Changjiang River (Table 2), with the age-3 and age-4 groups dominating, and the SL of each age group was larger than those recorded in our study. A similar situation was observed for C. guichenoti. Only three age classes (1-3) were recorded for C. guichenoti in our study, with age-1 group accounting for $67.0 \%$ of the total (Table 3). However, six age groups (age 


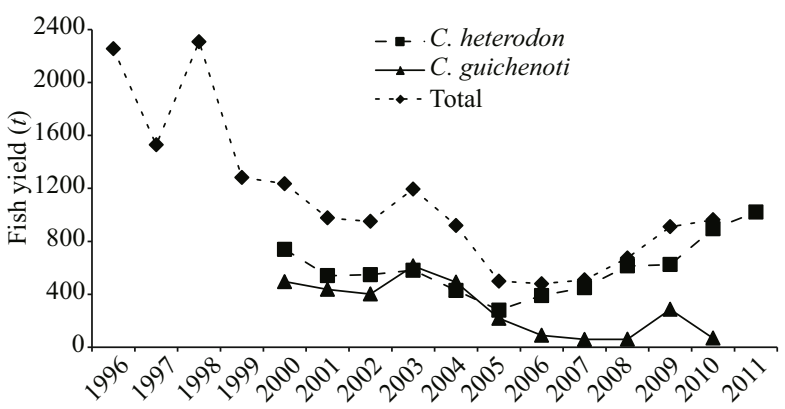

Fig.9 Dynamics of two Coreius species yield $(t)$ in the TGR, 1996-2011

Total fish yield is presented as the sum of $C$. heterodon and $C$. guichenoti.

2-7) for $C$. guichenoti were recorded in midstream areas (Wanzhou) of the TGR in 2005-2007 (Cheng, 2008). This differs noticeably from previous studies, which detected between five and seven age groups in the TGR area prior to 2007 in the Changjiang River. Total yield of the two Coreius species sharply declined after impoundment (SEPA, 1997-2012), especially for C. guichenoti (Fig.9).

\section{DISCUSSION}

\subsection{Status of Coreius sp, stocks in the TGR}

The results of the present study show differences in abundance, age structure, growth, condition and mortality of the two Coreius species between upstream, midstream and downstream areas of the TGR, suggesting that the construction of the dam had a profound effect on the distribution of both these lotic species. Closer to the dam, a lower fish abundance was observed. Declines in the relative abundance of lotic-adapted species after dam construction have been observed and reported in many studies (Martinez et al., 1994; Zhong and Power, 1996). Lotic species may move upstream to habitats that are more lotic in character as a result of damming (Wu et al., 2007; Gao et al., 2010; Yang et al., 2012) and fish abundance has been found to decrease significantly with depth (Moranta et al., 1998). Coreius species release floating eggs in upstream areas of the Changjiang River, which then drift downstream with the current (Liu et al., 1990). A large proportion of eggs may sink because of lower flow velocities, resulting in low recruitment and consequent reduced abundance close to the dam (Zhong and Power, 1996). The Three Gorges area, prior to the construction of the dam, was the largest spawning ground of $C$. heterodon in the Changjiang River (Xu et al., 1981; Liu et al., 1990).
However, in this study, no mature individuals were collected in the TGR, leading to the hypothesis that the reduction in older age groups and parental generation of the population could affect recruitment.

Closer to the dam, lower HSI values were observed. Changes in benthic communities after impoundment, resulting in variations in food supplies, could be the main reason for the phenomenon (Zhang et al., 2010). $C$. heterodon inhabits a limited area of the river for its whole life cycle, while $C$. guichenoti displays specific, migratory-like behavior (Luo et al., 2013). In Coreius species, the main component of the hepatopancreas is fat, which is used for energy storage (Ge et al., 2001). Thus, a high HSI is necessary in actively mobile, migratory species (e.g. C. guichenoti), which is consistent with our results. With dam construction in the upstream region of the Changjiang River, $C$. guichenoti experienced a loss of migratory pathways and even a change in migratory behavior (Luo et al., 2013), which could impinge on energy reserves.

\subsection{Impact of TGD on population structure}

Fish populations in non-regulated rivers normally have a larger number of age groups than those in regulated rivers (Torralva et al., 1997). After the final impoundment of the TGR, landings of Coreius were composed of young individuals, and each age group consisted of smaller-sized individuals than had been the case prior to impoundment. The shift towards a younger age structure in commercial landings could be a result of increased fishing pressure, hydropower development, environmental pollution (Yan, 2005; Cheng, 2008) or as a consequence of the ideal free distribution theory that populations increase with increasing habitat suitability while their size decreases (Blanchard et al., 2005).

The younger ages and smaller sizes recorded in the TGR may be explained as follows. First, the upstream area of the reservoir did not extend to Fuling and hydrological conditions remained basically unchanged when levels rose to $135 \mathrm{~m}$ a.s.l.; thus, the first phase of impoundment had little impact on Coreius. However, when water levels rose to $175 \mathrm{~m}$ a.s.l., the upstream area (Fuling) was flooded and environmental conditions changed greatly, with subsequent effects on Coreius populations. In the first-order tributaries within the upstream areas of the Changjiang River, Coreius species are mainly distributed in the Yalong, Jialing, Tuojiang, Minjiang and Wujiang Rivers (Anonymous, 1976; Ding, 1994; Yu et al., 2005). Cascade hydropower exploitation on 
these tributaries has blocked the migration paths of fish, and stocks of Coreius species have gradually declined in these areas (Jiang et al., 2007; Qing, 2010; Yang et al., 2011a, b; Zeng, 2012). Second, after final impoundment of the TGR, well-adapted lotic species or large individuals may have moved into the upper reaches of the river. This change in the age structure reflects to some extent how Coreius resources have been compromised in recent years.

Reservoir impoundment results in the loss of flowing-water habitats, changes in water temperature and water quality, variation in dissolved gases, sediment accumulation and the reduction of suitable spawning habitat (Walker, 1985; Wydoski and Hamill, 1991; Dadswell, 1996; Wang et al., 2014). Large reservoir impoundment may produce short-term variable flows during sluicing demand but constant flows otherwise, with a resulting lack of seasonal amplitude (Walker, 1985). Diffuse gradient hydraulic conditions formed after impoundment could affect fish behavior and delay downstream fish migration (Bednarek, 2001; Pelicice et al., 2014). Adaptation to changed environmental conditions could result in a decline in fish abundance and lower growth, via lost spawning grounds and delays in spawning time, as reported in carps in the Changjiang River (Wang et al., 2014). Increased water temperature due to dam construction may cause higher energy consumption and lower growth rates in fish (Luo and Wang, 2012). Therefore, the decrease in standard length at a given age of both Coreius species (Tables 2 and 3) in the TGR could be explained by changes in temperature. Invertebrate biomass and biodiversity were considerably depleted near the Thomson Dam, near Melbourne, Australia, associated with disturbed flows and siltation (Davey et al., 1982; Blyth, 1984). Therefore, altered benthic communities in the TGR could be another reason for this change, via bottomup effects (Chen and Wise, 1999; Shao et al., 2008). Upstream of the reservoir, the two Coreius species have become smaller at a given age. It is difficult to determine if this represent a genetic change or phenotypic plasticity, although damming accelerates genetic differentiation in populations living above versus below a dam (Cheng, 2010; Zhang et al., 2010). Actually, a reduction in fish abundance may result in larger body sizes, because of less competition for food and space. Rick (1981) found that, in pink salmon (Oncorhynchus gorbuscha), a reduction in body size could present an evolutionary response to selection. The water temperature, depth and flow preferences of young and mature Coreius need to be determined in future studies to evaluate ecological suitability and conservation management strategies.

Our results on asymptotic length, $L_{\infty}$, were similar to those from previous studies, showing that, for both species, values were lower than they had been before maximum impoundment (Zhuang and Cao, 1999; Chen et al., 2002; Zhou, 2010). The growth parameter, $k$, was lower for $C$. heterodon (Xu et al., 1981; Diao and Zhou, 1994; Chen et al., 2002) and higher for $C$. guichenoti (Yang et al., 2010, 2011a; Zhou, 2010) than it had been prior to the first stage of impoundment. Fish growth can be affected by hydrologic habitat (Rypel and Bayne, 2009), and the decrease in growth of the two Coreius species after damming in the TGR could be explained by changes in water temperature, as reported in whitefish (Prosopium williamsoni) after construction of the Libby Dam on the Kootenai River, Idaho, USA (Paragamian, 2002), and lower ecosystem productivity (Milbrink et al., 2011). The quantity, quality and size of food resources are often related to variations in population growth. One hypothesis that may explain the differences in growth rates is that, after impoundment of the TGR, benthic organisms failed to adapt to the new, deep-water environment, resulting in a lower biomass of available food which subsequently affected the growth of demersal fish. Any biological explanation for such a phenomenon remains to be clarified, but it may well be a specific feature of the Coreius population in the Changjiang River after impoundment. The gradual reduction in flow velocity from the upstream area of the reservoir towards the dam (SEPA, 2011) is demonstrated by the fact that the upstream area has the highest flow velocity and largest $k$ value.

The largest and majority of older specimens of $C$. heterodon and C. guichenoti were collected in the midstream and upstream areas of the TGR, respectively, indicating that midstream was more suitable for the growth of $C$. heterodon, and upstream was more suitable for $C$. guichenoti. Food availability and abiotic factors influence regional and intraspecific variations in growth (Claramunt and Wahl, 2000; Neuheimer and Taggart, 2007), and the relatively lower fishing mortality may be another reason for the improved growth.

In the TGR, a higher natural mortality $(M)$, lower total mortality $(Z)$ and lower fishing mortality $(F)$ were found for $C$. heterodon compared with values recorded before the first stage of impoundment (Chen et al., 2002), whereas, for $C$. guichenoti, $Z$ and $M$ 
values were higher and the $F$ value was slightly lower than in previous studies (Chen et al., 2002; Yang, 2009). Inappropriate habitat and lower growth rates influence mortality rates (Griffiths and Harrod, 2007). Higher temperatures caused higher metabolic rates, resulting in more frequent foraging, which increases the chances of encountering predators and indirectly affects mortality rates (Pauly, 1980). Fishing mortality rates have declined in recent years because of the enforcement of closed seasons and stricter fishery management. The exploitation rate $(E=F / Z)$ for the two Coreius species was $>0.5$, which indicates a possible decline in stocks (Patterson, 1992). Therefore, these fishery management practices and policies need to be enforced for the long-term protection, conservation and stock restoration of these two Coreuis species.

\subsection{Management implications}

In the TGR, stocks of Coreius species have been in decline. After final impoundment of the TGR, the demographic structure of the Coreius populations inhabiting the area changed, with young individuals becoming more abundant and mature individuals progressively disappearing. The consequences of dam construction combined with the impact of commercial fishing leaves lotic populations, such as Coreius species, in a fragile situation that must be addressed urgently.

Long-term protection and conservation is required to rebuild the reproductive potential and age structure of Coreius populations, and aid in their recovery. It is recommended that fishery managers should consider the following points: (1) limit fishing effort. In particular, limit the number of fish hooks and set minimum landing sizes that are above the size-atmaturity of the species. This will ensure that immature and developing fish (which now dominate the populations in near-dam areas) will reach sexual maturity before capture; (2) ban fishing during breeding seasons, especially in the Jinsha River (upstream of the Changjiang River). The closed season should be extended and fishery surveillance increased to enforce these restrictions. At present, the closed season in the Changjiang River extends from February to April, which does not cover the breeding activities of Coreius sp., which take place between April and July (Cheng, 2008; Zhang, 2009). In addition, opening all sluice gates during the spawning season would be advantageous to migratory fish in terms of nursery grounds (Jutagate et al., 2007), as would the construction of fish passes on the Jinsha River so that migratory fish can access spawning grounds more easily (Gowans et al., 2003). Management of the fishery is clearly necessary for population recovery, but it is often insufficient. Habitat conservation also needs to be consideredthe entire river system should be protected. In addition to rehabilitating environmental conditions, the fish fauna needs to be rebuilt in this region. In the 1950s, for example, paddlefish in the Missouri River were protected by a river habitat conservation directive (Elser, 1986). Artificial propagation is another possible rehabilitation measure. In the Changjiang River, $C$. guichenoti migrate to the Jinsha River to mature and reproduce; however, this migration path has been blocked by cascading hydroelectric dams. Therefore, stock enhancement appears to be the only, rapidly effective method for preventing collapse of the $C$. guichenoti population. Therefore, artificial propagation of $C$. guichenoti should be actively considered. Impoundment has adverse impacts on benthic organisms, but a reduction in peak flows may enhance the recovery of benthic fauna (Cowx et al., 1998). Thus, a new flow-management system could be introduced to reduce the adverse effects of damming on the benthos, which is the primary food resource of Coreius species (Xu et al., 1981; Liu et al., 2012). Finally, the status of these food resources within the reservoir, which play an important role in the condition of Coreius species, with consequences for growth, natural mortality and reproductive potential (Lloret et al., 2014), need to be properly evaluated because, at present, little is known about them.

\section{CONCLUSION}

The life-history traits of these two lotic species, Coreius heterodon and C. guichenoti, have been significantly affected by impoundment along the longitudinal profile of the Three Gorges Reservoir area. Lower abundance, slower growth, a less diversified age structure, poorer condition (indicated by the hepatosomatic index) and higher mortalities were recorded in areas nearest the dam compared with upstream areas. The results indicate that the two Coreius species were subject to dramatic changes after impoundment the Changjiang (Yangtze) River and creation of the reservoir. These changes could have resulted from alterations in habitat (with decreasing water flow rates), water temperature and food availability. Fishery management, conservation and 
restoration policies to rehabilitate the stock biomass of these species need to be implemented urgently.

\section{References}

Anonymous. 1976. Fishes of the Yangtze River. Department of Ichthyology. Science Press, Beijing. p.73-77. (in Chinese)

Bednarek A T. 2001. Undamming rivers: a review of the ecological impacts of dam removal. Environ. Manage., 27(6): 803-814.

Beverton R J H, Holt S J. 1956. A review of methods for estimating mortality rates in exploited fish populations, with special reference to sources of bias in catch sampling. Rapp. P.-v. Réun. Cons. Int. Explor. Mer., 140(1): 67-83.

Blanchard J L, Mills C, Jennings S, Fox C J, Rackham B D, Eastwood P D, O'Brien C M. 2005. Distribution abundance relationships for North Sea Atlantic cod (Gadus morhua): observation versus theory. Can. J. Fish. Aquat. Sci., 62(9): 2 001-2 009.

Blyth J D. 1984. The influence of particulate matter on stream invertebrates-case studies of Dartmouth and Thomson Dams. In: Hart B T ed. The Role of Particulate Matter in the Transport and Fate of Pollutants. Water Studies Centre, Chisholm Inst. Technol., Melbourne. p.194-195.

Cambray J A, King J M, Bruwer C. 1997. Spawning behaviour and early development of the Clanwilliam yellowfish (Barbus capensis; Cyprinidae), linked to experimental dam releases in the Olifants River, South Africa. Regul. Rivers. Res. Manage., 13(6): 579-602.

Chang M H, Lin Y S, Chaung L C. 1999. Effect of dams on fish assemblages of the Tachia River, Taiwan. Acta Zool. Taiwanica, 10(2): 77-90.

Chen B R, Wise D H. 1999. Bottom-up limitation of predaceous arthropods in a detritus-based terrestrial food web. Ecology, 80(3): 761-772.

Chen D Q, Liu S P, Duan X B, Xiong F. 2002. A preliminary study of the fisheries biology of main commercial fishes in the middle and upper reaches of the Yangtze River. Acta Hydrobiologia Sinica, 26(6): 618-622. (in Chinese with English abstract)

Cheng F. 2010. Temporal and Spatial Patterns of Ichthyoplankton between Yibin and Chongqing Section and Genetic Structure of Procypris rabaudi Tchang and Coreius heterodon Bleeker in the Yangtze River. Dessertation, Institute of Hydrobiology, Chinese Academy of Sciences, Wuhan. (in Chinese with English abstract)

Cheng P. 2008. The Biology of Coreius guichenoti (Sauvage et Dabry) in the Upper Reaches of the Yangtze River. Dessertation, Huazhong Agricultural University, Wuhan. (in Chinese with English abstract)

Claramunt R M, Wahl D H. 2000. The effects of abiotic and biotic factors in determining larval fish growth rates: a comparison across species and reservoirs. Trans. Am. Fish. Soc., 129(3): 835-851.

Cowx I G, O'Grady K T, Parasiewicz P, Schmutz S, Moog O. 1998. The effect of managed hydropower peaking on the physical habitat, benthos and fish fauna in the River
Bregenzerach in Austria. Fisheries Manag. Ecol., 5(5): 403-417.

Cushman R M. 1985. Review of ecological effects of rapidly varying flows downstream from hydroelectric facilities. N. Am. J. Fish. Manage., 5(3A): 330-339.

Dadswell M J. 1996. The removal of Edwards Dam, Kennebec River, Maine: its effects on the restoration of anadromous fishes. In: Draft Environmental Impact Statement, Kennebec River, Maine, Appendices. p.1-3.

Davey G W, Brooks P, Blyth J D. 1982. Substrata, sediment and current as determinants of aquatic invertebrate distribution in relation to construction of the Thomson Dam. Rep. Nat. Mus. Vie, 2: 212.

Torralva M D M, Puig M A, Fernández-Delgado C. 1997. Effect of river regulation on the life-history patterns of Barbus sclateri in the Segura river basin (south-east Spain). J. Fish. Biol., 51(2): 300-311.

Diao X M, Zhou R S. 1994. The preliminary study on age and growth of Coreius heterodon. Sichuan Journal of Zoology, 13(1): 32-33. (in Chinese)

Ding R H. 1994. The Fishes of Sichuan. Sichuan Publishing House of Science and Technology, Chengdu. p.273-278. (in Chinese)

Dynesius M, Nilsson C. 1994. Fragmentation and flow regulation of river systems in the northern third the world. Science, 266(5186): 753-762.

Elser AA. 1986. An overview of current management practices for paddlefish fisheries. In: Dillard J G ed. The Paddlefish: Status, Management and Propagation. American Fisheries Society, North Central Division, Special Publication No.7. p.62-67.

Fu B J, Wu B F, Lü Y H, Xu Z H, Cao J H, Niu D, Yang G S, Zhou Y M. 2010. Three gorges project: efforts and challenges for the environment. Prog. Phys. Geog., 34(6): 741-754.

Galat D L, Fredrickson L H, Humburg D D et al. 1998. Flooding to restore connectivity of regulated, large-river wetlands. BioScience, 48(9): 721-733.

Gao X. 2007. Conservation Biology of Rare and Endemic Fishes of the Yangtze River. Dissertation, Institute of Hydrobiology, Chinese Academy of Sciences, Wuhan. (in Chinese with English abstract)

Gao X, Zeng Y, Wang J W, Liu H Z. 2010. Immediate impacts of the second impoundment on fish communities in the Three Gorges Reservoir. Environ. Biol. Fish., 87(2): 163173.

Ge Q X, Wang Z J, Zhang H X. 2001. Study on the hepatopancreases of Coreius heterodon (Bleeker) and Coreius guichenoti (Sauvage et Dabry) in Yangtze River. Journal of Quanzhou Normal College (Natural Science), 19(6): 69-74. (in Chinese with English abstract)

Gehrke P C, Gilligan D M, Barwick M. 2002. Changes in fish communities of the Shoalhaven River 20 years after construction of Tallowa Dam, Australia. River Res. Appl., 18(3): 265-286.

Gerritsen H D, McGrath D. 2007. Precision estimates and suggested sample sizes for length-frequency data. Fish. 
Bull., 105(1): 116-120.

Gleick P H. 1993. Water in Crisis: a Guide to the World's Fresh Water Resources. Oxford Univ. Press, Inc., New York. $473 \mathrm{p}$.

Gowans A R D, Armstrong J D, Priede I G, Mckelvey S. 2003. Movements of Atlantic salmon migrating upstream through a fish-pass complex in Scotland. Ecol. Freshw. Fish., 12(3): 177-189.

Greathouse E A, Pringle C M, McDowell W H, Holmquist J G. 2006. Indirect upstream effects of dams: consequences of migratory consumer extirpation in Puerto Rico. Ecol. Appl., 16(1): 339-352.

Griffiths D, Harrod C. 2007. Natural mortality, growth parameters, and environmental temperature in fishes revisited. Can. J. Fish. Aquat. Sci., 64(2): 249-255.

Han M, Fukushima M, Kameyama S, Fukushima T, Matsushita B. 2008. How do dams affect freshwater fish distributions in Japan? Statistical analysis of native and nonnative species with various life histories. Ecol. Res., 23(4): 735743.

He X F. 1980. The biology of Coreius heterodon (Bleeker). Journal of Southwest China Normal University (Natural Science), (2): 60-76. (in Chinese with English abstract)

He Y F, Wang J W, Lek-Ang S, Lek S. 2010. Predicting assemblages and species richness of endemic fish in the upper Yangtze River. Sci. Total Environ., 408(19): 4 2114220.

Hoenig J M. 1983. Empirical use of longevity data to estimate mortality rates. Fish. Bull., 82(1): 898-903.

Hoenig J M, Lawing W D. 1982. Estimating the total mortality rate using the maximum-order statistic for age. Int. Counc. Explor. Sea. C.M./D: 7. p.13.

Holmquist J G, Schmidt-Gengenbach J M, Yoshioka B B. 1998. High dams and marine-freshwater linkages: effects on native and introduced fauna in the Caribbean. Conserv. Biol., 12(3): 621-630.

Jackson D C, Marmulla G. 2001. The influence of dams on river fisheries. In: Marmulla $\mathrm{G}$ ed. Dams, Fish and Fisheries: Opportunities, Challenges and Conflict Resolution. FAO Fish. Tech. Pap. No.419, Rome. p.1-44.

Jia J S, Yuan Y L, Zheng C Y, Ma Z L. 2010. Dam construction in China: statistic, progresses and concerned issues. Hydropower, 36(1): 6-10. (in Chinese with English abstract)

Jiang H, Xie S G, Zhao W Q, Chang J B. 2007. Changes of fish assemblages after construction of Ertan reservoir in Yalongjiang River. Acta Hydrobiologica Sinica, 31(4): 532-539. (in Chinese with English abstract)

Jutagate T, Thapanand T, Tabthipwan P. 2007. Is sluice gate management beneficial for spawning migrations? The case of the shark catfish (Helicophagus waandersii) in the Mun River below the Pak Mun Dam, Thailand. River Res. Appl., 23(1): 87-97.

Katano O, Nakamura T, Abe S, Yamamoto S, Baba Y. 2006. Comparison of fish communities between above- and below-dam sections of small streams; barrier effect to diadromous fishes. J. Fish. Biol., 68(3): 767-782.
Leng Y Z, He L T, Wei Q H. 1984. Population biology and resources estimate of Coreius heterodon in the upper reaches of the Changjiang River after the construction of Gezhouba Dam. Freshwater Fisheries, (5): 21-25. (in Chinese)

Liermann C R, Nilsson C, Robertson J, Ng R Y. 2012. Implications of dam obstruction for global freshwater fish diversity. BioScience, 62(6): 539-548.

Liu F, Dan S G, Wang J W, Cao W X. 2012. Feeding habits of Coreius guichenoti (Sauvage et Dabry) in the upper Yangtze River. Acta Hydrobiologica Sinica, 36(6): 1081 1 086. (in Chinese with English abstract)

Liu J K, Cao W X. 1992. Fish resources of the Yangtze River basin and the tactics for their conservation. Resources and Environment in the Yangtze Basin, 1(1): 17-23. (in Chinese with English abstract)

Liu L H, Wu G X, Wang Z L. 1990. Reproduction ecology of Coreius heterodon (Bleeker) and Coreius guichenotj (Sauvage et Dabry) in the mainstream of the Changjiang River after the construction of Gezhouba Dam. Acta Hydrobiologica Sinica, 14(3): 205-215. (in Chinese with English abstract)

Liu X W. 2009. The Feasibility of Restoration the Chinese Sturgeon (Acipenser sinensis) Population in the Upper Reaches of Yangtze River: Macroinvertebrates Surveys and Releasing Trail. Dissertation, Huazhong Agricultural University, Wuhan. (in Chinese with English abstract)

Lloret L, Shulman G, Love R M. 2014. Condition and Health Indicators of Exploited Marine Fish. Wiley-Blackwell, UK. 356p.

Luo Y P, Huang Q D, Zhang Y R, Liu S T, Wang W. 2013. Comparison of the body proximate compositions of juvenile bronze gudgeon (Coreius heterodon) and largemouth bronze gudgeon (C. guichenoti) in the upstream region of the Yangtze River. SpringerPlus, 2(1): 1-6. http: //www.springerplus.com/content/2/1/75.

Luo Y P, Wang Q Q. 2012. Effects of body mass and temperature on routine metabolic rate of juvenile largemouth bronze gudgeon Coreius guichenoti. J. Fish. Biol., 80(4): 842-851.

Lü Y B, Gong Z Y, Lian J, Wang Q, Xian H, Li G G. 2007. Status of water quality in the Three Gorges after water storage period. Research of Environmental Sciences, 20(1): 1-6. (in Chinese with English abstract)

Martinez P J, Chart T E, Trammell M A, Wullschleger J G, Bergersen E P. 1994. Fish species composition before and after construction of a main stem reservoir on the White River, Colorado. Environ. Biol. Fish., 40(3): 227-239.

Maunder M N, Wong R A. 2011. Approaches for estimating natural mortality: application to summer flounder (Paralichthys dentatus) in the US mid-Atlantic. Fish. Res., 111(1-2): 92-99.

Milbrink G, Vrede T, Tranvik L J, Rydin E. 2011. Large-scale and long-term decrease in fish growth following the construction of hydroelectric reservoirs. Can. J. Fish. Aquat. Sci., 68(12): 2 167-2 173.

Moranta J, Stefanescu C, Massutí E, Morales-Nin B, Lloris D. 
1998. Fish community structure and depth-related trends on the continental slope of the Balearic Islands (Algerian basin, western Mediterranean). Mar. Ecol. Prog. Ser., 171: $247-259$.

Mugabe F T, Hodnett M G, Senzanje A. 2003. Opportunities for increasing productive water use from dam water: a case study from semi-arid Zimbabwe. Agr. Water. Manage., 62(2): 149-163.

MWR (Ministry of Water Resources, People's Republic of China). 2011. Statistic Bulletin on China Water Activities. China Water Conservancy and Hydropower Press, Beijing. p.39-40, http: //www.mwr.gov.cn/zwzc/hygb/ slfztjgb/201212/P020121231374294531411.pdf.

Neuheimer A B, Taggart C T. 2007. The growing degree-day and fish size-at-age: the overlooked metric. Can. J. Fish. Aquat. Sci., 64(2): 375-385.

Nilsson C, Reidy C A, Dynesius M, Revenga C. 2005. Fragmentation and flow regulation of the world's large river systems. Science, 308(5720): 405-408.

Paragamian V L. 2002. Changes in the species composition of the fish community in a reach of the Kootenai River, Idaho, after construction of Libby Dam. J. Freshwater Ecol., 17(3): 375-383.

Park Y S, Chang J B, Lek S, Cao W X, Brosse S. 2003. Conservation strategies for endemic fish species threatened by the Three Gorges Dam. Conserv. Biol., 17(6): $1748-1758$.

Patterson K. 1992. Fisheries for small pelagic species: an empirical approach to management targets. Rev. Fish. Biol. Fish., 2(4): 321-338.

Pauly D. 1980. On the interrelationships between natural mortality, growth parameters, and mean environmental temperature in 175 fish stocks. J. Cons. Int. Explor. Mer., 39(2): 175-192.

Pauly D, David N. 1981. ELEFAN I, a BASIC program for the objective extraction of growth parameters from lengthfrequency data. Meeresforschung, 28(4): 205-211.

Pelicice F M, Pompeu P S, Agostinho A A. 2014. Large reservoirs as ecological barriers to downstream movements of Neotropical migratory fish. Fish. Fish., published Online First, 24 July 2014, http: //onlinelibrary. wiley.com/doi/10.1111/faf.12089/abstract.

Perera H A C C, Rypel A L, Murphy B R, Li Z J, Xia Y G, Liu J S. 2013. Population characteristics of yellow catfish (Peltobagrus fluvidraco) along the longitudinal profile of Three Gorges Reservoir, China. J. Appl. Ichthyol., 29(5): $1061-1066$.

Qing H. 2010. Patterns of Fishes Diversity in Jialing River and Resources Vicissitude in the Middle and Lower Basin. Dissertation, Southwest University, Chongqing. (in Chinese with English abstract)

Ricker W E. 1981. Changes in the average size and average age of Pacific salmon. Can. J. Fish. Aquat. Sci., 38(12): $1636-1656$.

Rypel A L, Bayne D R. 2009. Hydrologic habitat preferences of select southeastern USA fishes resilient to river ecosystem fragmentation. Ecohydrology, 2(4): 419-427.
SEPA (State Environmental Protection Administration). 19972012. Eco-environmental Monitoring Bulletin of the Three Gorges Project in the Yangtze River, http: //www. tgenviron.org/monbulletin/monjournal.html. (in Chinese)

Shao M L, Xie Z C, Han X Q, Cao M, Cai Q H. 2008. Macroinvertebrate community structure in Three Gorges Reservoir, China. Int. Rev. Hydrobiol., 93(2): 175-187.

Tang H Y, Yang Z, Gao S B, Chen J S, Zhang Y C, Wan L, Qiao Y. 2012. Status of fish resources of early life history stages of Coreius guichenoti in the middle reaches of the Jinsha River. Sichuan Journal of Zoology, 31(3): 416-421, 425. (in Chinese with English abstract)

Thorp J H, Black A R, Haag K H, Wehr J D. 1994. Zooplankton assemblages in the Ohio River: seasonal, tributary, and navigation dam effects. Can. J. Fish. Aquat. Sci., 51(7): $1634-1643$.

Walker K F. 1985. A review of the ecological effects of river regulation in Australia. Hydrobiologia, 125(1): 111-129.

Wang J N, Li C, Duan X B, Chen D Q, Feng S X, Luo H H, Peng Q D, Liao W G. 2014. Variation in the significant environmental factors affecting larval abundance of four major Chinese carp species: fish spawning response to the Three Gorges Dam. Freshw. Biol., 59(7): 1 343-1 360.

WCD (The World Commission on Dams). 2000. Dams and Development: a New Framework for Decision-Making: the Report of the World Commission on Dams. Earthscan Publications, London, England, http: //www.dams.org/ report/.

Wu J G, Huang J H, Han X G, Gao X M, He F L, Jiang M X, Jiang Z G, Primack R B, Shen Z H. 2004. The Three Gorges Dam: an ecological perspective. Front. Ecol. Environ., 2(5): 241-248.

Wu J G, Huang J H, Han X G, Xie Z Q, Gao X M. 2003. Three Gorges Dam-experiment in habitat fragmentation? Science, 300(5623): 1 239-1 240.

Wu Q, Duan X B, Xu S Y, Xiong C X, Chen D Q. 2007. Studies on fishery resources in the Three Gorges Reservoir of the Yangtze River. Freshw. Fish., 37(2): 70-75. (in Chinese with English abstract)

Wydoski R S, Hamill J. 1991. Evolution of a cooperative recovery program for endangered fishes in the Upper Colorado River Basin. In: Minckley W L, Deacon J E eds. Battle against Extinction: Native Fish Management in the American West. University of Arizona Press, Tucson. p.123-139.

Xenopoulos M A, Lodge D M. 2006. Going with the flow: using species-discharge relationships to forecast losses in fish biodiversity. Ecology, 87(8): 1 907-1 914.

Xia Z Y. 2011. The Distributing Characteristics of Plant Species and Plant Community Diversity in the WaterLevel-Fluctuating Zone of Three Gorges Reservoir. Dissertation, Southwest University, Chongqing. (in Chinese with English abstract)

Xie S G, Li Z J, Liu J S, Xie S Q, Wang H Z, Murphy B R. 2007. Fisheries of the Yangtze River show immediate impacts of the Three Gorges Dam. Fisheries, 32(7): 343344. 
Xu K H, Milliman J D. 2009. Seasonal variations of sediment discharge from the Yangtze River before and after impoundment of the Three Gorges Dam. Geomorphology, 104(3-4): 276-283.

Xu Y G, Deng Z L, Yu Z T, Wei X J. 1981. The biological aspects of Coreius heterodon (Bleeker) and the effects of proposed Sanxia hydroelectric project on its resource. Acta Hydrobiologica Sinica, 7(3): 271-293. (in Chinese with English abstract)

Yan L. 2005. Studies on Biology of Stocks and Genetic Diversity of Coreius heterodon (Bleeker). Dissertation, Huazhong Agricultural University, Wuhan. (in Chinese with English abstract)

Yang Q R, Chen Q W, Ma X F. 2011. Status of fish resources and protection measures in the lower reaches of Yalong River. Journal of Hydroecology, 32(3): 94-98. (in Chinese with English abstract)

Yang S R, Gao X, Li M Z, Ma B S, Liu H Z. 2012. Interannual variations of the fish assemblage in the transitional zone of the Three Gorges Reservoir: persistence and stability. Environ. Biol. Fish., 93(2): 295-304.

Yang S R, Ma B S, Kong Y, Zhou C, Liu H Z. 2010. Growth features of juvenile Coreius guichenoti and its conservation in the Three Gorges Reservoir. Resources and Environment in tne Yangtze Basin, 19(Z2): 52-57. (in Chinese with English abstract)

Yang Z. 2009. Study on Population Biology of Largemouth Bronze Gudgeon (Coreius guichenoti) of the Middle and Upper Reaches of the Yangtze River. Dissertation, Institute of Hydrobiology, Chinese Academy of Sciences, Wuhan. (in Chinese with English abstract)

Yang Z, Qiao Y, Zhang Y C, Zhu D, Chang J B. 2009. Estimate on population mortality of Coreius guichenoti and its conservation in the middle and upper Yangtze River. Journal of Hydroecology, 2(2): 50-55. (in Chinese with English abstract)

Yang Z, Wan L, Tao J P, Cai Y P, Zhang Y Y, Qiao Y. 2011a. Age and growth of Coreius guichenoti in the mainstream of the Yangtze River. Journal of Hydroecology, 32(4): 4652. (in Chinese with English abstract)

Yang Z, Zheng H T, Xiong M H, Hu J X, Qiao Y, Wang X, Zhang Y C, Chang J B. 2011b. Variation characteristics of fish community structure and biodiversity in Autumn before and after impoundment of Pengshui hydropower station. Environmental Science \& Technology, 34(8): 2229. (in Chinese with English abstract)

Yu X D, Luo T H, Zhou H Z. 2005. Large-scale patterns in species diversity of fishes in the Yangtze River Basin. Biodiversity Science, 13(6): 473-495. (in Chinese with
English abstract)

Yu Z T, Liang Z S, Yi B L. 1984. The early development of Coreius heterodon and Coreius guichenoti. Acta Hydrobiologica Sinica, 8(4): 371-380. (in Chinese with English abstract)

Yuan X P, Yan L, Xu S Y, Wang D Q, Zhang Y, Chen D Q. 2008. Genetic diversity of bronze gudgeon (Coreius heterodon) and largemouth bronze gudgeon ( $C$. guichenoti) in Yangtze River Basin. Journal of Fishery Sciences of China, 15(3): 377-385. (in Chinese with English abstract)

Zeng H. 2006. Phytoplankton in Yangtze and Three Gorges Reservoir: Dynamics and Relationship with Nutrients and Hydrological Conditions. Dissertation, Institute of Hydrobiology, Chinese Academy of Sciences, Wuhan. (in Chinese with English abstract)

Zeng Y. 2012. Studies on ecological structure of fish community in Jialing River. Resources and Environment in the Yangtze Basin, 21(7): 850-857. (in Chinese with English abstract)

Zhang F T, Tan D Q. 2010. Genetic diversity in population of largemouth bronze gudgeon (Coreius guichenoti Sauvage et Dabry) from Yangtze River determined by microsatellite DNA analysis. Genes Genet. Syst.,, 85(5): 351-357.

Zhang M, Shao M L, Xu Y Y, Cai Q H. 2010. Effect of hydrological regime on the macroinvertebrate community in Three Gorges Reservoir, China. Quatern. Int., 226(12): $129-135$.

Zhang Y C. 2009. Impact of Dam on Natural Reproduction of Coreius guichenoti and Rhinogobio ventralis in Upstream of Yangtze River. Dissertation, Institute of Hydrobiology, Chinese Academy of Science, Wuhan. (in Chinese with English abstract)

Zheng S M, Xiong Q M. 1993. The study on the fine structure of the ovary of Coreius heterodon. Journal of Wuhan University (Natural Science Edition), (3): 103-109. (in Chinese with English abstract)

Zhong Y G, Power G. 1996. Environmental impacts of hydroelectric projects on fish resources in China. Regul. Rivers Res. Manage., 12(1): 81-98.

Zhou C. 2010. Growth and Population Characteristics of Coreius guichenoti (Sauvage et Dabry) in the Upper Reaches of Yangtze River. Dissertation, Shandong University, Jinan. (in Chinese with English abstract)

Zhuang P, Cao W X. 1999. Growth characteristics of Coreius heterodon in the middle and upper reaches of the Yangtze River. Acta Hydrobiologica Sinica, 23(6): 577-583. (in Chinese with English abstract) 